\title{
Optimized labeling of bone marrow mesenchymal cells with superparamagnetic iron oxide nanoparticles and in vivo visualization by magnetic resonance imaging
}

Jasmin ${ }^{1,2^{*}}$, Ana Luiza M Torres ${ }^{1}$, Henrique MP Nunes ${ }^{1}$, Juliana A Passipieri', Linda A Jelicks ${ }^{3}$, Emerson L Gasparetto ${ }^{4}$, David C Spray ${ }^{2}$, Antonio C Campos de Carvalho ${ }^{1,2}$, Rosalia Mendez-Otero ${ }^{1}$

\begin{abstract}
Background: Stem cell therapy has emerged as a promising addition to traditional treatments for a number of diseases. However, harnessing the therapeutic potential of stem cells requires an understanding of their fate in vivo. Non-invasive cell tracking can provide knowledge about mechanisms responsible for functional improvement of host tissue. Superparamagnetic iron oxide nanoparticles (SPIONs) have been used to label and visualize various cell types with magnetic resonance imaging (MRI). In this study we performed experiments designed to investigate the biological properties, including proliferation, viability and differentiation capacity of mesenchymal cells (MSCs) labeled with clinically approved SPIONs.
\end{abstract}

Results: Rat and mouse MSCs were isolated, cultured, and incubated with dextran-covered SPIONs (ferumoxide) alone or with poly-L-lysine (PLL) or protamine chlorhydrate for 4 or 24 hrs. Labeling efficiency was evaluated by dextran immunocytochemistry and MRI. Cell proliferation and viability were evaluated in vitro with Ki67 immunocytochemistry and live/dead assays. Ferumoxide-labeled MSCs could be induced to differentiate to adipocytes, osteocytes and chondrocytes. We analyzed ferumoxide retention in MSCs with or without mitomycin C pretreatment. Approximately 95\% MSCs were labeled when incubated with ferumoxide for 4 or 24 hrs in the presence of PLL or protamine, whereas labeling of MSCs incubated with ferumoxide alone was poor. Proliferative capacity was maintained in MSCs incubated with ferumoxide and PLL for 4 hrs, however, after 24 hrs it was reduced. MSCs incubated with ferumoxide and protamine were efficiently visualized by MRI; they maintained proliferation and viability for up to 7 days and remained competent to differentiate. After 21 days MSCs pretreated with mitomycin C still showed a large number of ferumoxide-labeled cells.

Conclusions: The efficient and long lasting uptake and retention of SPIONs by MSCs using a protocol employing ferumoxide and protamine may be applicable to patients, since both ferumoxides and protamine are approved for human use.

\section{Background}

Stem cell transplantation has been explored as a new method to prevent or reverse deleterious effects of several types of tissue injury [1,2]. Mesenchymal stem cells (MSCs) derived from bone marrow have the capacity to differentiate into a number of mesenchymal phenotypes,

\footnotetext{
* Correspondence: jasmin@biof.ufrj.br

'Instituto de Biofísica Carlos Chagas Filho, Universidade Federal do Rio de Janeiro, Rio de Janeiro, Brazil

Full list of author information is available at the end of the article
}

including adipocytes, osteocytes, chondrocytes and myocytes [3-5]. Moreover, MSCs seem to be immunosuppressive, being able to inhibit $\mathrm{T}$ cell proliferation in vitro and the function of both naive and memory $\mathrm{T}$ cells [6-8] and to suppress the development of monocyte-derived dendritic cells in an in vitro system [9]. All these features together with the fact that MSCs can be culture-expanded in large numbers show their great potential to repair or reconstitute a wide array of organs [10]. 
The success of stem cell therapies in patients requires methods to determine the biodistribution and fate of stem cells without postmortem histology, and the lack of tracking data represents a serious obstacle for the clinical use of cell therapy. Thus, the development of sensitive, non-invasive techniques for tracking cells can provide knowledge about the poorly understood mechanisms responsible for the improvement that has been described in several lesion models [11-13]. Magnetic resonance imaging (MRI) is an excellent tool for high-resolution visualization of the fate of cells after transplantation and for evaluation of cell-based repair, replacement, and therapeutic strategies [13-18]. In addition, this technique has been also used for in vivo visualization of endogenous neural stem/progenitor cell migration from subventricular zone in normal and injured animal brains [19-21].

For in vivo cell tracking, contrast agents such as superparamagnetic iron oxide nanoparticles (SPIONs) have been successfully used for labeling different mammalian cell types [11,22-25]. Ferumoxides are dextrancoated SPIONs clinically used as an intravenous MRI contrast agent for analyzing liver pathology. The nanoparticles are phagocytosed and accumulate in endosomes of Kupffer cells and reticuloendothelial cells [26]. The particles are biodegradable and incorporated into hemoglobin in red cells within 30 to 40 days or integrated into other metabolic processes [27]. SPIONs tend to aggregate and this has been reduced by coating with dextran or other polymers [28]. Unfortunately, dextrancoated SPIONs do not show sufficient cellular uptake to enable tracking of nonphagocytic cells [29]. However, the cellular uptake of SPIONs by nonphagocytic cells can be facilitated by cationic compounds such as polyL-lysine (PLL) [29,30] and protamine sulfate [31-33] due to their interaction with the negatively charged cell surface and subsequent endosomal uptake $[29,34]$. PLL is a synthetic cationic polymer commonly used to enhance cell adhesion to the surface of culture dishes. However, its use has not yet been approved in humans. Protamines are low-molecular-weight arginine-rich proteins $(\sim 4000 \mathrm{Da})$, that are purified from the mature testes of fish. Protamine sulfate is an FDA approved polycationic peptide primarily used as an antidote for heparin anticoagulation $[35,36]$. It has been administered i.v. to humans at doses of 600-800 mg with minimal toxicity and is well-tolerated by cells in vitro [37].

Approval for clinical MRI tracking of labeled stem cells depends on efficient cell labeling that does not exhibit cellular toxic effects and does not elicit side effects. Labeling of MSCs with SPIONs has been studied by a number of groups over the past several years [38-40], but no studies have completely characterized the effects of SPIONs on cell proliferation, survival and differentiation and have concurrently shown retention of these labeling particles for long times.

In this work, we carried out a thorough study on the effect of the SPIONs in MSCs using a refined protocol and we compared two different compounds used to facilitate the incorporation of ferumoxides into the cells, poly-L-lysine and protamine. We analyzed the efficiency of SPIONs to label MSCs during short- or long-term exposure (4 or $24 \mathrm{hrs}$ ) both in vivo and in vitro. Furthermore, we investigated the retention time of SPIONs in the cells for up to 21 days and we analyzed the influence of SPION labeling, using our protocol, on the biological properties (proliferation, viability and differentiation) of MSCs. Our results demonstrate the high potential for long-term SPIONs labeling of MSCs using clinically approved substances.

\section{Methods}

\subsection{Animals}

Experiments were performed on adult male Wistar syngeneic rats (8-12 weeks old) or C57BL/6 mice (8-10 weeks old). All experiments were performed in accordance with the U.S. National Institutes of Health Guide for the Care and Use of Laboratory Animals (NIH Publication No. 80-23), and were approved by the Committee for the Use of Experimental Animals at our institutions (Universidade Federal do Rio de Janeiro and Albert Einstein College of Medicine).

Only mice were used for MRI experiments since our MRI coils are too small to accommodate rats. All other experiments were performed on rats.

\subsection{Isolation and Cultivation of Rat/Mouse Mesenchymal Cells from Bone Marrow}

To obtain bone marrow cells, tibias and femurs were isolated, the epiphyses were removed, the bones were individually inserted in $1 \mathrm{~mL}$ automatic pipette polypropylene tips and then put in $15 \mathrm{~mL}$ tubes. The bones were centrifuged at $300 \times \mathrm{g}$ for $1 \mathrm{~min}$ and the pellets suspended in Dulbecco's modified Eagle's medium F-12 (DMEM F-12; Invitrogen Inc., Carlsbad, CA, http://www.invitrogen.com ), supplemented with $10 \%$ fetal bovine serum (FBS; Invitrogen Inc.), 2 mM l-glutamine (Invitrogen Inc.), $100 \mathrm{U} / \mathrm{mL}$ penicillin (Sigma-Aldrich Co., St. Louis, MO, http://www. sigmaaldrich.com), and $100 \mu \mathrm{g} / \mathrm{mL}$ streptomycin (SigmaAldrich Co.). Mononuclear cells were purified by centrifugation in Histopaque 1083 (Sigma-Aldrich Co.) gradient at $400 \times \mathrm{g}$ for 30 minutes. After three washes in phosphate-buffered saline (PBS) using centrifugations at $300 \times \mathrm{g}$, the cells were plated in $75 \mathrm{~cm}^{2}$ flasks with supplemented DMEM F-12 and maintained in 5\% $\mathrm{CO}_{2}$ atmosphere at $37^{\circ} \mathrm{C}$. The medium was replaced $48-72 \mathrm{hrs}$ after initial culture to remove nonadherent cells and the adherent cells were grown to confluence before each 
passage. Medium was replaced three times a week. All experiments were performed on third passage cells.

\subsection{MSC Labeling}

In the present study we used a clinically approved contrast agent, ferumoxide (Feridex IV, Advanced Magnetics Inc., Cambridge, MA, http://www.amagpharma. com). The physical properties of Feridex are as follows: the core iron size is $5 \mathrm{~nm}$, and the hydrodynamic size including the dextran coat is $80-150 \mathrm{~nm}$ [38]. To improve the incorporation, a final concentration of $5.0 \mu \mathrm{g} / \mathrm{mL}$ protamine chlorhydrate (Valeant Pharmaceuticals International, São Paulo, SP, Brazil, http://www. valeant.com) or $375 \mathrm{ng} / \mathrm{mL}$ PLL ( $\mathrm{MW}=389.000$; Sigma-Aldrich Co.) was used as a facilitator agent. In Brazil, protamine chlorhydrate is clinically approved by The National Health Surveillance Agency (ANVISA) and it has been used as a substitute for protamine sulfate in rescue of heparin anticoagulation.

Protamine chlorhydrate and PLL were separately combined with Feridex in culture medium and gently shaken for 30 minutes at room temperature. The solutions containing Feridex and PLL (FePLL) or protamine (FeProt) were added to adherent cell cultures at a proportion of 1:1 in supplemented DMEM F-12. The final concentration of Feridex in all treated groups was $25 \mu \mathrm{g} / \mathrm{mL}$. All the groups used in this study are listed in Table 1 except the groups described in section 2.7.

\subsection{Prussian Blue Staining}

After incubation with Feridex, the Prussian blue (PB) method was used to detect iron within the cells in culture. This method induces a reduction of ferric iron to the ferrous state with the formation of a blue ferrocyanide precipitate. For PB staining, MSCs were cultured

Table 1 Experimental groups

\begin{tabular}{|c|c|c|c|}
\hline Group Name & $\begin{array}{l}\text { Transfection } \\
\text { Agent }\end{array}$ & $\begin{array}{l}\text { Feridex } \\
\text { Exposure Time }\end{array}$ & $\begin{array}{l}\text { Experiment } \\
\text { duration }\end{array}$ \\
\hline CTRL & None & None & 24 hours \\
\hline CTRL/3d & None & None & 3 days \\
\hline CTRL/7d & None & None & 7 days \\
\hline PLL 24 h & Poly-L-lysine & None & 24 hours \\
\hline Prot $24 \mathrm{~h}$ & Protamine & None & 24 hours \\
\hline Fe $4 \mathrm{~h}$ & None & 4 hours & 4 hours \\
\hline Fe $24 \mathrm{~h}$ & None & 24 hours & 24 hours \\
\hline FePLL $4 \mathrm{~h}$ & Poly-L-lysine & 4 hours & 4 hours \\
\hline FePLL 24 h & Poly-L-lysine & 24 hours & 24 hours \\
\hline FeProt $4 \mathrm{~h}$ & Protamine & 4 hours & 4 hours \\
\hline FeProt $24 \mathrm{~h}$ & Protamine & 24 hours & 24 hours \\
\hline FeProt $4 \mathrm{~h} / 24 \mathrm{~h}$ & Protamine & 4 hours & 24 hours \\
\hline FeProt $4 \mathrm{~h} / 3 \mathrm{~d}$ & Protamine & 4 hours & 3 days \\
\hline FeProt 4 h/7d & Protamine & 4 hours & 7 days \\
\hline
\end{tabular}

on glass coverslips coated with $0.2 \%$ gelatin, washed twice with warm PBS and fixed for $20 \mathrm{~min}$ in $4 \%$ paraformaldehyde at $37^{\circ} \mathrm{C}$. After fixation, the cells were washed twice with PBS and incubated with Perls' reagent (20\% potassium ferrocyanide and $20 \%$ hydrochloric acid) for $20 \mathrm{~min}$ at room temperature. Cultures were then washed once in deionized water, dehydrated through graded alcohols and mounted with Entellan (Merck KGaA, Darmstadt, Germany, http://www.merck.de). Samples were observed by light microscopy.

\subsection{Immunocytochemistry}

For immunofluorescence, MSCs were grown and fixed as described above. The cells were washed three times with PBS with $0.1 \%$ Triton X-100, incubated with 5\% normal goat serum (Sigma-Aldrich) in PBS for $30 \mathrm{~min}$, and then incubated with the primary antibody overnight at $4{ }^{\circ} \mathrm{C}$. The MSCs were then incubated with the secondary antibody and mounted with VectaShield (Vector Laboratories Inc., Burlingame, CA, http://www.vectorlabs.com). Immunostaining with anti-dextran (1:1000; mouse monoclonal, Stem Cell Technologies, Vancouver, BC, http://www.stemcell.com) was used to detect Feridex incorporation efficacy by different treatments. The proliferation rate of MSCs labeled with Feridex was evaluated by immunostaining with anti-Ki67 (1:400, rabbit monoclonal, Abcam Inc., Cambridge, MA, http://www. abcam.com).

The secondary antibodies used in this study were: Alexa 488-conjugated goat-anti-mouse IgG (1:400; Invitrogen Inc.) and Cy3-conjugated goat-anti-rabbit IgG (1:1,000; Jackson ImmunoResearch Inc., West Grove, PA, http://www.jacksonimmuno.com). The cell nuclei were counterstained with $0.1 \%$ 4',6-diamidino-2-phenylindole (DAPI, Sigma-Aldrich Co.).

\subsection{Feridex-Labeled MSC Viability/Cytotoxicity}

The effect of Feridex on viability of MSCs was determined by Live/dead viability/cytotoxicity kit (Invitrogen Inc.) for up to 7 days after initial exposure. Feridex labeled MSCs were incubated with $1 \mu \mathrm{M}$ calcein AM (green) and $2 \mu \mathrm{M}$ ethidium homodimer (EthD-1; red) in PBS for $10 \mathrm{~min}$ in $5 \% \mathrm{CO}_{2}$ atmosphere at $37^{\circ} \mathrm{C}$. Thereafter, the glass coverslips containing the MSCs were mounted onto slides, viewed by fluorescent microscopy and the ratio of live/dead (green/red) cells determined.

\subsection{In Vitro Retention of Feridex in MSCs}

In this study we analyzed the duration of Feridex retention in MSCs. The groups described in this section are not listed in Table 1.

We analyzed the number of labeled cells up to 21 days of culture. After initial FeProt incubation for $4 \mathrm{hrs}$, the cells were trypsinized weekly and the number of cells 
labeled with Feridex was counted at the following time points: $1,7,14$ and 21 days (this group was called FeProt 7/7d).

Because cells in culture proliferate more rapidly than in vivo, we used Mitomycin $C$ to reduce proliferation rate. Thus, we incubated the cells with $10 \mu \mathrm{g} / \mathrm{mL}$ Mitomycin $\mathrm{C}$ for 3 hrs before FeProt incubation for 4 hrs, and as described for the FeProt 7/7d the cells were trypsinized weekly and the number of labeled cells was counted at the following time points: 1,7, 14 and 21 days (this group was called FeProt MitC). We chose Mitomycin $C$ to reduce cellular proliferation since it has been widely used for inhibition of cell proliferation in several cell types.

For both groups described above, we used trypsin during the experiment. To control for the possibility that the trypsinization process might interfere with exocytose of the Feridex, we created a group in which no trypsinization was done. In this group the cells were labeled with FeProt for 4 hrs and maintained in culture for 21 days without trypsinization (this group was called FeProt 21d).

\subsection{Differentiation Studies}

To determine if Feridex labeling had adverse effects on MSC differentiation, we performed adipogenic, osteogenic and chondrogenic differentiation assays. MSC cells were incubated with FeProt for 4 hrs before starting the differentiation protocol. Control samples were maintained in supplemented DMEM F-12. In all differentiation studies, the medium was changed every 2-3 days. After differentiation, the cells were fixed as described below.

\subsubsection{Adipogenic Differentiation}

To verify the adipogenic differentiation potential of labeled MSCs, $\sim 70 \%$ confluent cells were cultivated for 3 weeks in DMEM F-12 supplemented with $1 \mu \mathrm{M}$ dexamethasone, $10 \mu \mathrm{g} / \mathrm{mL}$ insulin, $0.5 \mu \mathrm{M}$ isobutylemethylxanthine and $200 \mu \mathrm{M}$ indomethacin. The cells were stained with $0.2 \%$ Oil Red O for 30 minutes to reveal the intracellular accumulation of lipid-rich vacuoles. All reagents used in this experiment were from SigmaAldrich Co.

\subsubsection{Osteogenic Differentiation}

Osteogenic differentiation was performed with medium supplemented with $1 \mu \mathrm{M}$ dexamethasone, $10 \mathrm{mM} \beta$-glycerolphosphate, and $0.5 \mu \mathrm{M}$ ascorbic phosphate for 3 weeks. Calcium deposits were evidenced by $1 \%$ Alizarin Red staining for 30 minutes in water. All reagents used in this experiment were from Sigma-Aldrich Co.

\subsubsection{Chondrogenic Differentiation}

To investigate chondrogenic differentiation potential, labeled MSCs were trypsinized and resuspended in supplemented DMEM-F12 at $1.6 \times 10^{7}$ cells $/ \mathrm{mL}$. To form micromass cultures, the cells were seeded in $7 \mu \mathrm{l}$ droplets in the center of 24 well plates and cultivated under high humidity conditions. After 2 hrs chondrogenesis media (Invitrogen Inc.) was added to the culture plates and the cells were cultivated for 2 weeks. The micromass formed was embebbed in paraffin, sectioned and the presence of proteoglycans was evaluated by $1 \%$ Alcian Blue (Sigma-Aldrich Co.) staining in 3\% acetic acid (Sigma-Aldrich Co.) solution for $30 \mathrm{~min}$.

\subsection{In Vivo MRI}

To confirm that labeled MSCs could be detected by MRI, mouse cells labeled with FeProt for 4 or 24 hrs were injected $\left(3 \times 10^{6}\right.$ cells in $30 \mu \mathrm{L}$ of PBS) through the medial surface in the adductor muscles of the hind leg. In these experiments, we used C57BL/6 mice instead of rats since our MRI coils are too small to accommodate rats. The mouse MSCs were isolated and cultivated as described above (2.1). Labeled MSCs were injected into the muscle $18 \mathrm{hrs}$ before the imaging experiment. To perform the MRI, the animals were anesthetized with isofluorane (2-3\% in medical air administered via a nose cone). Mice were positioned head-up in the MRI coil in a 9.4-T GE Omega vertical bore imaging system (Fremont, CA, http://www.gehealthcare. com) equipped with an S50 shielded gradient microimaging accessory and a $40 \mathrm{~mm}$ inner diameter- $60 \mathrm{~mm}$ long ${ }^{1} \mathrm{H}$ quadrature birdcage imaging coil. Body temperature was maintained by a water-heating system. Transverse plane images of the mouse at the position of the hind limbs were acquired using a $51-\mathrm{mm}$ field of view with a $128 \times 256$ matrix size (interpolated to $256 \times$ 256). Routine spin-echo imaging was performed due to limitations of the vertical bore MRI system hardware. Eight contiguous $1 \mathrm{~mm}$ thick images were acquired with a $300 \mathrm{~ms}$ repetition time (TR) and an $18 \mathrm{~ms}$ echo time (TE); 4 scans were averaged. Each set of 8 images was acquired in approximately $3 \mathrm{~min}$. In plane, resolution was 200 microns.

We used the ImageJ program (from U.S. National Institutes of Health, Bethesda, MD) to quantify the mean intensity of the dark spots.

After imaging, the mouse was sacrificed and the leg muscles were fixed in $4 \%$ paraformaldehyde overnight and incubated with $20 \%$ sucrose (Sigma-Aldrich Co.) in PBS for at least $24 \mathrm{hrs}$ in $4^{\circ} \mathrm{C}$ for cryopreservation. Thereafter, the tissues were incubated in optimal cutting temperature resin (Sakura Finetek USA Inc., Torrance, CA, http://www.sakuraus.com) and $10 \mu \mathrm{m}$ frozen sections were collected on microscope slides.

\subsection{In Vitro MRI}

After labeling with FeProt for 4 hrs, mouse MSCs were washed three times with PBS, trypsinized, fixed for 
20 minutes in $4 \%$ paraformaldehyde in $1.5 \mathrm{~mL}$ tubes and resuspended in $300 \mu \mathrm{l}$ of $15 \%$ gelatin. Tubes containing 10,000 unlabeled cells/ $\mu$ l and 3,330, 1,660 and 166 labeled cells/ $\mu \mathrm{l}$ were positioned in the same coil used for in vivo experiments. For this experiment, TR was $1 \mathrm{~s}$, TE was $15 \mathrm{~ms}$, and four $0.5 \mathrm{~mm}$ thick contiguous images were acquired with the same spin-echo sequence used for in vivo imaging. To maximize signal to noise and instrument usage, in vitro experiments were set up to run overnight (approximately 9 hours) with 256 scans signal averaged and increased in-plane resolution (100 microns).

The Image program (from U.S. National Institutes of Health) was used to quantify the mean intensity of the acquired images from the $1.5 \mathrm{~mL}$ tubes.

\subsection{Microscope Image Acquisition}

The photomicrographs shown in this study were obtained using an Axiovert $200 \mathrm{M}$ microscope (Zeiss, GmbH, Germany, http://www.zeiss.com) equipped with ApoTome system, Axiovert 135 microscope (Zeiss) or a Nikon Eclipse TE300 microscope (Nikon Co., Tokyo, Japan, http://www.nikon.com). Quantifications were performed using AxioVision 4.8 software (Zeiss).

\subsection{Statistical analysis}

At least three independent experiments were performed for each statistical analysis. For quantification of labeling, we acquired random images of each sample using a $20 \mathrm{x}$ objective and the number of labeled MSCs with florescent probes was quantified as a percentage of the total number of cells. For ferumoxide incorporation and proliferation rate, we acquired 6 images from different fields per sample and the total number of stained cells was divided by the total number of DAPI-stained cells. For live/dead assays, we acquired 8 images from different fields per sample and we divided the number of green or red cells by the total number of cells (green plus red cells). The number of samples (n) used for quantification is indicated in the figures. Brightfield images were acquired to facilitate the quantification of ferumoxide incorporation by MSCs. It was used to determine the membrane boundaries and to distinguish dextran-positive cells from the background.

Statistical significance was evaluated using one-way ANOVA with Bonferroni's post-test for comparison among multiple groups and t-test for comparison between 2 groups. All calculations were done using GraphPad Prism 5 for Windows (GraphPad Software, San Diego, CA, http://www.graphpad.com).

\section{Results}

\subsection{MSC Labeling and Proliferation}

Presence of iron nanoparticles within the cells was confirmed by staining with Prussian Blue (Figure 1A) or

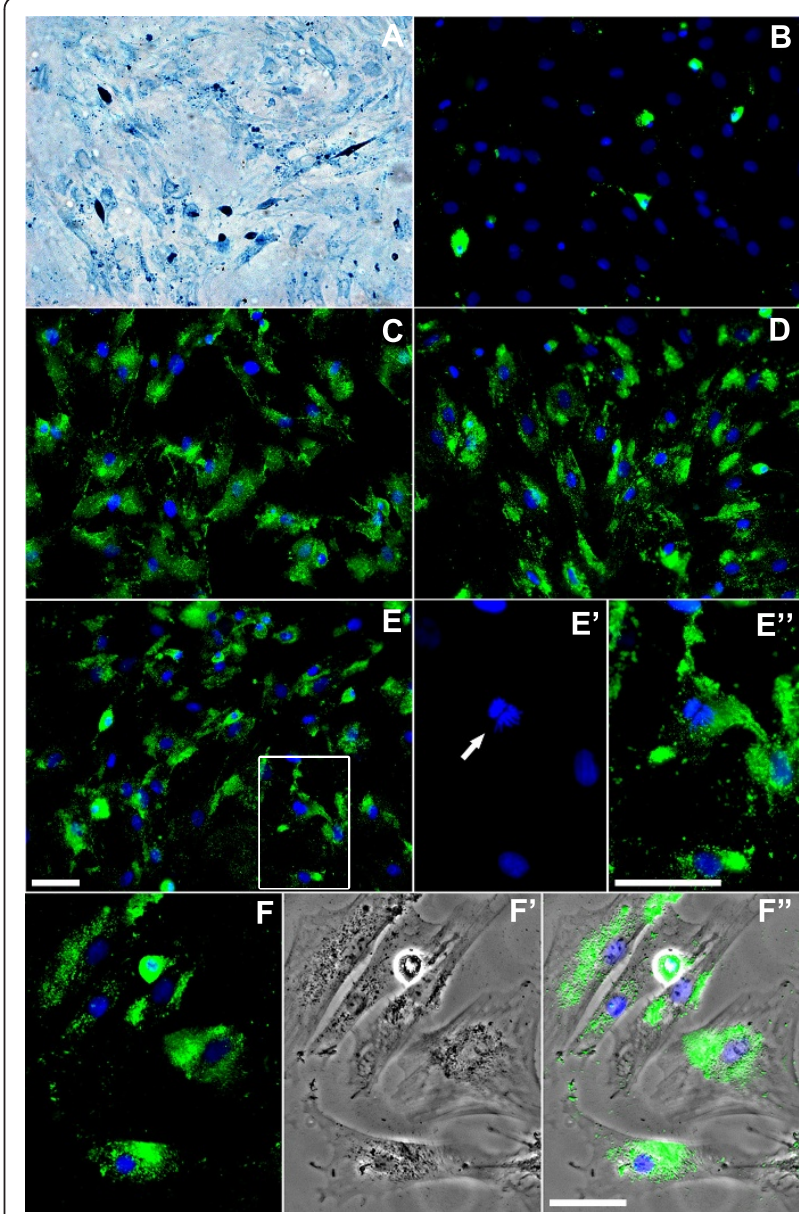

Figure 1 Representative images demonstrating labeling of MSCs with Feridex in the absence or presence of agents facilitating uptake of the nanoparticles. $\left(\mathbf{A}-\mathrm{F}^{\prime \prime}\right)$ Presence of Feridex in MSCs was detected by Prussian Blue staining or by dextran immunoreactions. (A) Prussian Blue staining in MSCs incubated with FePLL for 24 hrs. Note that virtually all cells display blue intracellular staining. (B-F") Representative images showing dextran immunostaining (green) in MSCs labeled with Feridex and nuclei counterstained with DAPI (blue). (B) Cells incubated with Feridex for 24 hrs in the absence of facilitating agents. (C-F") MSCs exposed to Feridex in the presence of an agent facilitating incorporation (C) FeProt for 4 hrs. (D) FePLL for 24 hrs. (E) FeProt for 24 hrs. ( $\left.\mathbf{E}^{\prime}-\mathbf{E}^{\prime \prime}\right)$ Higher-magnification image of the area indicated by the box in (E) illustrating a Feridex-labeled cell whose nucleus is counterstained with DAPI undergoing mitotic division. (E') Mitotic cell (arrow). ( $\left.\mathbf{E}^{\prime \prime}\right)$ Merged image showing DAPI and dextran immunostaining. (F-F") Representative images demonstrating the characteristic perinuclear distribution of Feridex in MSCs after 4 hrs of incubation with FeProt (F) DAPI and dextran immunostaining. $\left(\mathbf{F}^{\prime}\right)$ Brightfield. $\left(\mathbf{F}^{\prime \prime}\right)$ Merger of the images. Scale bar $=50 \mu \mathrm{m}$.

anti-dextran antibody (Figure 1B-F“). The Prussian Blue technique was used only to confirm the presence of iron in the cells since we used anti-dextran antibody for quantification of Feridex-positive cells and this antibody only recognizes the dextran coating. It was suggested that dextran coating can undergo degradation when 
taken up by macrophages [41]. Thus, a limitation in our quantifications is a potential underestimation of the number of labeled MSCs. Efficient Feridex uptake was not observed when the cells were incubated with Feridex without an incorporation facilitator for either 4 or 24 hrs (Figure 2A). However, MSC were efficiently labeled with Feridex when incubated with the facilitating agents, either PLL (Figure 2B) or protamine (Figure 2C). In addition, we did not observe decrease in the number of labeled cells with Feridex at 3 or 7 days after the initial $4 \mathrm{hr}$ incubation with FeProt (Figure 2D).

All groups (except for the group exposed to FePLL for $24 \mathrm{hrs}$, which showed a lower proliferation rate) incubated with Feridex alone or in combination with incorporation facilitator for 4 or $24 \mathrm{hrs}$ maintained their proliferative capacity when compared to the control group (Figure 2E-G). In addition, no alterations in proliferation rate were observed when we analyzed proliferation for longer periods ( 3 or 7 days) in the groups exposed to FeProt complexes for 4 hrs comparing with their respective controls (Figure $2 \mathrm{H}$ ). However, as shown in Figure $2 \mathrm{H}$, the proliferation rate decreased after 7 days of culture when compared with the cultures of 3 days. In the CTRL/7d and FeProt/7d groups, we plated half the amount of cells plated in the CTRL/3d and FeProt/3d groups but the cells approached confluence at 7 days, and the decrease in proliferation rate is probably due to the confluence.

\subsection{Labeled MSC Viability}

Live/dead assays were performed in cultures for up to 7 days to evaluate Feridex-labeled MSC viability. Viability assays demonstrated no difference in MSC live/dead ratio after exposing the cells to FeProt for 4 or $24 \mathrm{hrs}$ (Figure 3A) when compared to the control group. Moreover, after longer periods (3 or 7 days) of observation, we did not find alterations in MSC viability after $4 \mathrm{hr}$ exposure to FeProt (Figure 3B-C).

\subsection{In Vitro Retention of Feridex in MSCs}

We analyzed the duration of Feridex retention in MSCs in vitro for up to 21 days after initial incubation with FeProt for 4 hrs. After 21 days of culture we observed a decrease of $66.1 \%, 32.8 \%$ and $19.4 \%$ in the number of cells labeled with Feridex in the groups FeProt 7/7d, FeProt 21d and FeProt MitC, respectively (Figure 4A-C). As shown in Figure 4D, the number of MSCs labeled with Feridex was significantly greater in FeProt MitC than in the other groups. In addition, the group FeProt 21d showed a higher number of cells labeled when compared with the group FeProt $7 / 7 \mathrm{~d}$. The fraction of cells labeled with Feridex shown was obtained by immunostaining to dextran, but the presence of iron nanoparticles was confirmed by Prussian Blue staining after 21 days of culture (data not shown).

\subsection{Differentiation Studies}

Differentiation assays were performed in vitro in both unlabeled and $4 \mathrm{hrs}$ FeProt labeled MSCs. Staining for intracellular accumulation of lipid-rich vacuoles with Oil Red O revealed that MSCs maintained adipogenic capacity after Feridex incorporation (Figure 5A-B). Also, the osteogenic potential, evidenced by calcium deposits stained with Alizarin Red, was not affected by Feridex labeling (Figure 5C-D). In non-induced cultures we did not observe adipogenic or osteogenic differentiation (data not shown). In addition, unlabeled and Feridexlabeled cells induced toward chondrogenic differentiation formed micromasses that were not observed in non-induced cultures (data not shown). Staining for Alcian Blue revealed the differentiation toward chondrocytes of both unlabeled and labeled cells (Figure 5E-F). Thus, we concluded that FeProt labeling does not impact MSC differentiation into adipocyte, osteocyte or chondrocyte lineages.

\subsection{In vivo and in vitro MRI}

MSCs labeled with Feridex for either 4 or 24 hrs were detected in mouse tissues by in vivo MRI. In the transverse image shown in Figure 6A, the hypointense (dark) spots, indicated by white arrows, show Feridex-labeled cells detected in the mouse legs; the right leg was injected with cells incubated with FeProt for 4 hrs and left leg was injected with cells incubated with FeProt for $24 \mathrm{hrs}$. There is no apparent difference in the intensity of dark spots in MSCs incubated with FeProt for these different labeling durations. Immunoreaction to dextran confirmed the presence of Feridex-labeled cells in the right and left legs (Figure 6B-C "'). In addition, labeled MSCs were detected by in vitro MRI. Dark spots were observed in Feridex-labeled cells with density corresponding to number of labeled cells; there was no MRI detection of unlabeled cells, even when the concentration of cells was high (Figure 6D).

\section{Discussion}

Extending knowledge about the effect of SPION incorporation by stem cells is essential for clinical approval of this technique and for its use in tracking stem cells after transplantation. In this study, we evaluated the effect of clinically approved SPIONs in MSCs after short and long-term exposure using the incorporation facilitators PLL and protamine.

The protocol used in this study is different from those used by others. Our choices were based on the following reasoning. The most commonly used concentrations of Feridex are 25, 50 and $100 \mu \mathrm{g} / \mathrm{mL}$. It was shown that efficient uptake of Feridex (15 to 20 pg of intracytoplasmatic iron/cell) can be achieved using $25 \mu \mathrm{g} / \mathrm{mL}$ Fe and $750 \mathrm{ng} / \mathrm{mL}$ PLL in MSC $[30,42]$. Recently, another 


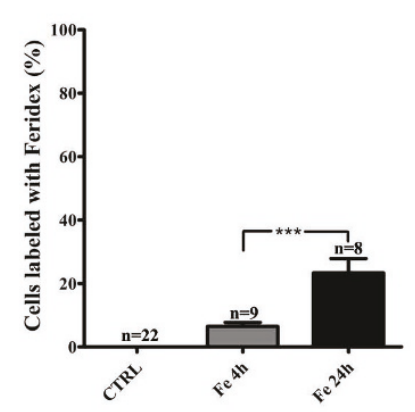

A
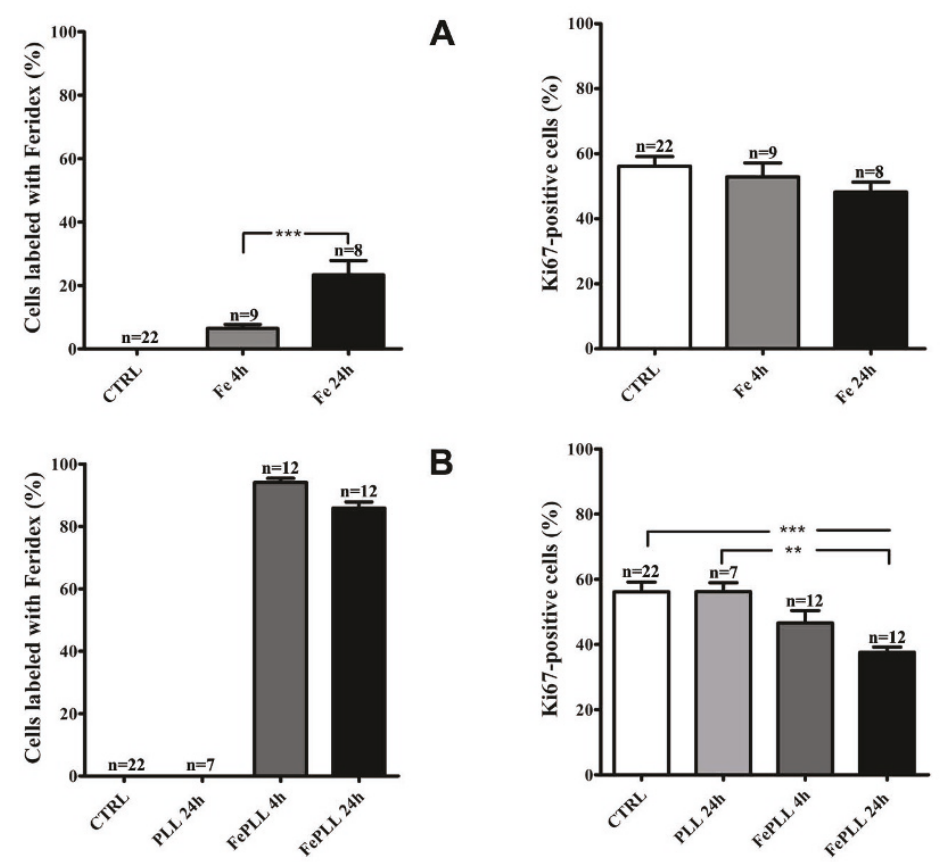

B

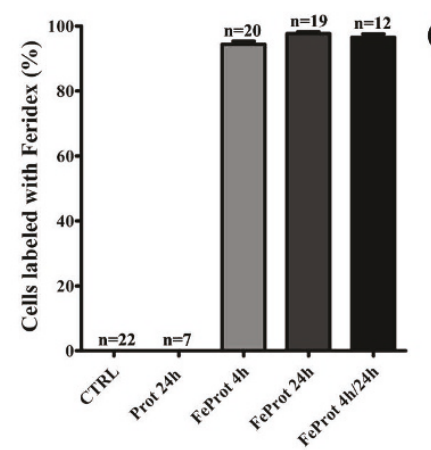

C

D

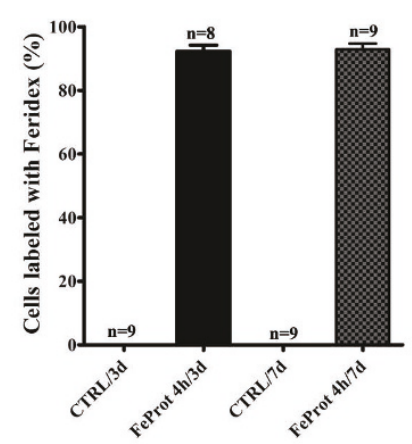

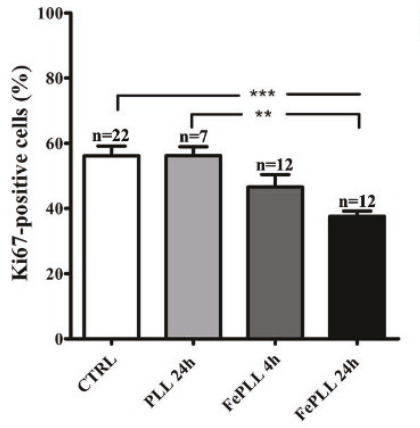

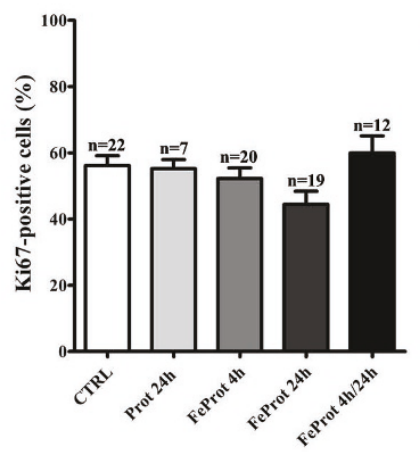

E

$\mathbf{F}$

G

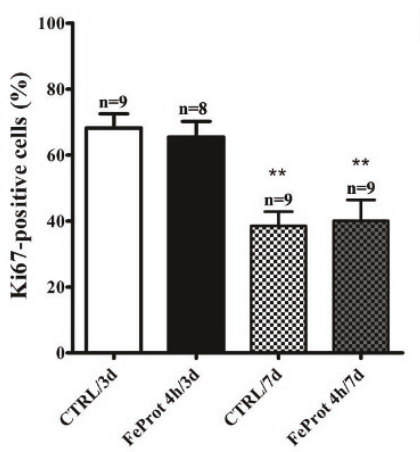

Figure 2 Quantification of labeling efficacy and proliferation rate of MSCs incubated with Feridex. (A-D) Evaluation of MSC cell labeling by Feridex and/or agents facilitating incorporation for 4 or 24 hrs. (A) Cells incubated with Feridex alone for 4 or 24 hrs showed little incorporation. (B) Cells exposed to Feridex and PLL showed an efficient incorporation rate. (C) Cells exposed to Feridex and protamine showed efficient incorporation of Feridex. (D) Quantification of labeling efficacy of MSCs incubated with FeProt complexes for 4 hrs and cultured for up 7 days. The number of cells labeled with Feridex was constant even after 7 days of Feridex incorporation. (E-H) Evaluation of proliferative capacity of MSCs exposed to Feridex and/or incorporation facilitator agents for 4 or 24 hrs. Alteration in proliferation rate was observed in MSCS incubated with FePLL complexes for 24 hrs; no change in proliferation was observed in the other groups. (E) Cells incubated with Feridex without an incorporation facilitator for 4 or 24 hrs. (F) MSCs labeled with Feridex and PLL for 4 or 24 hrs. (G) MSCs labeled with Feridex and protamine for 4 or 24 hrs. (H) Measurements of proliferative capacity of MSCs incubated with FeProt complexes for 4 hrs and cultured for up 7 days. The proliferation rate was maintained even after 7 days of Feridex incorporation. The " $n$ " indicated on the top of the bars is the number of samples used for the quantification of each group. Error bars represent SEM. ${ }^{* *} P<0.01$ and ${ }^{* * *} P<0.001$. 


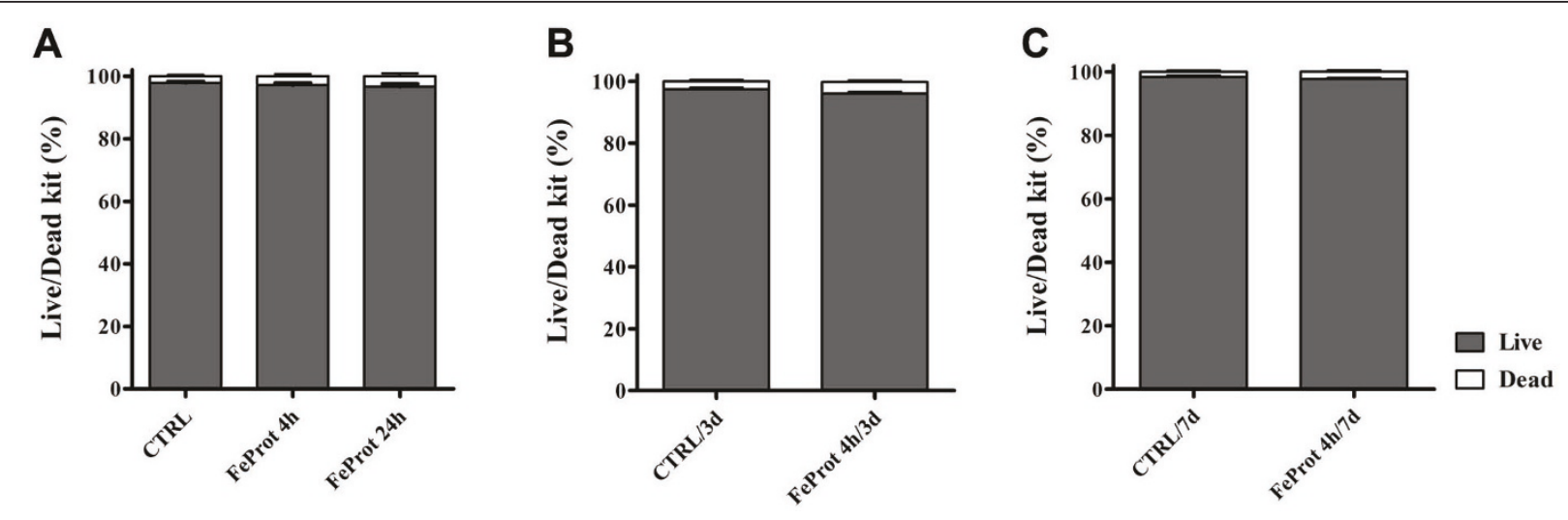

Figure 3 Evaluation of MSC viability after exposure to FeProt complexes. (A-C) Viability was measured by live/dead assays in live MSCs incubated with FeProt complexes for 4 or 24 hrs. No change in MSCs viability was observed at different time points (A) MSCs exposed to FeProt complexes for 4 or 24 hrs. (B-C) Viability of MSCs cultured for up 7 days after initial exposure to FeProt complexes for 4 hrs. (B) 3 days after initial incubation. (C) 7 days after initial incubation. ( $N=9$, for each group). Error bars represent SEM.

group compared four different concentrations of Feridex in human umbilical cord MSCs $(5.6,11.2,22.4$, and $44.8 \mu \mathrm{g} / \mathrm{mL}$ Feridex) and showed that $44.8 \mu \mathrm{g} \mathrm{Fe} / \mathrm{mL}$ was toxic for the cells in MTT test [43]. Based on this information we chose to use a low concentration of Feridex $(25 \mu \mathrm{g} / \mathrm{mL})$ in the present study.
In addition, it was shown that the intracellular uptake of iron (pg/cell) is not altered when the ratio of Feridex to protamine varied three fold, from $50: 3$ FeProt $\mu \mathrm{g} / \mathrm{mL}$ to $50: 9 \mathrm{FeProt} \mu \mathrm{g} / \mathrm{mL}$ [31]. However when a lower concentration of Feridex was used with a lower concentration of protamine (25:0.75 FeProt $\mu \mathrm{g} / \mathrm{mL})$, efficient
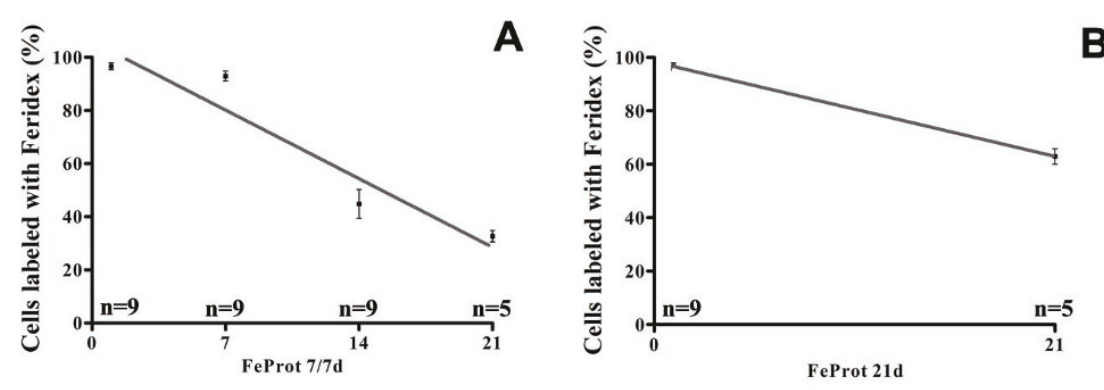

B
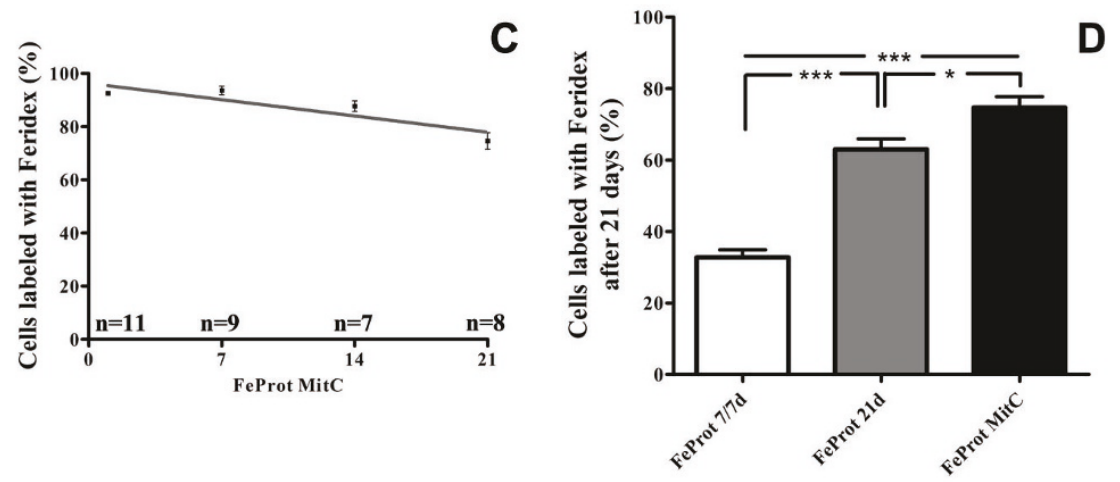

Figure 4 Quantitative analysis of the duration of Feridex retention in MSCs pretreated or not with mitomycin C. (A-D) MSCS cultured for up 21 days after initial exposure to FeProt complexes for 4 hrs. (A) Feridex-labeled cells trypsinized weekly and evaluated after 1, 7, 14 and 21 days of culture. (B) The number of MSCs labeled after 1 and 21 days of culture without trypsinization. (C) Mitomycin-pretreated cells labeled with Feridex and trypsinized weekly. The number of MSCs labeled was evaluated after 1, 7, 14 and 21 days of culture. (D) Comparison of the number of MSCs labeled with Feridex after 21 days of culture in the groups illustrated in (A-C). The percentage of labeled cells was significantly higher in FeProt MitC than in the other groups. The " $n$ " indicated on the top of the bars is the number of samples used for the quantification of each time point. Error bars represent SEM. ${ }^{*} P<0.05$ and ${ }^{* *} P<0.001$. 


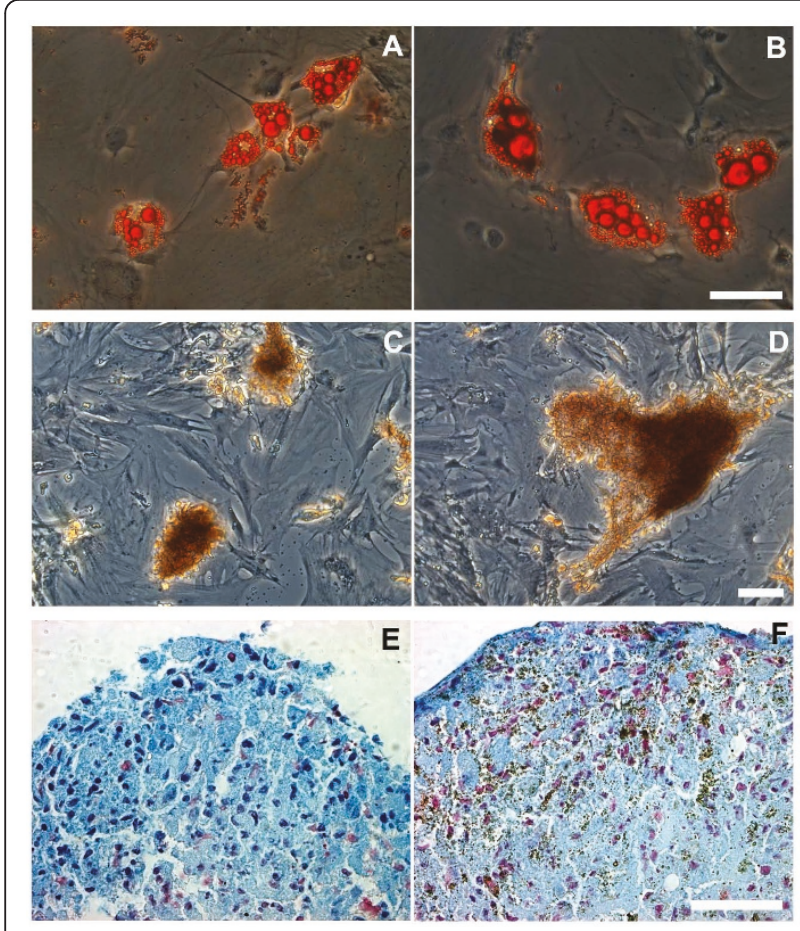

Figure 5 Analysis of the differentiation potential of MSCs labeled with FeProt complexes for $\mathbf{4}$ hrs. (A-B) Oil Red $O$ staining indicating adipogenesis in unlabeled or Feridex-labeled cells. (A) Unlabeled cells induced toward adipocyte differentiation. (B) Labeled MSCs induced toward adipocyte differentiation. (C-D) Alizarin Red staining showing osteogenic differentiation in MSCS labeled with Feridex or not. (C) Unlabeled cells induced toward osteocyte differentiation. (D) Labeled cells induced toward osteocyte differentiation. (E-F) Alcian Blue staining showing chondrogenesis in unlabeled or Feridex-labeled MSCs. The nuclei were counterstained with Nuclear Fast Red. (E) Unlabeled cells induced to chondrogenic differentiation. (F) Labeled cells induced to chodrogenesis. The brown deposits in figure $(F)$ indicate the presence of SPIONs. No apparent alteration in differentiation potential was observed due to Feridex labeling in MSCs. Scale bar = $50 \mu \mathrm{m}$.

labeling was not obtained [32]. Therefore, our choice of 25:5 FeProt $\mu \mathrm{g} / \mathrm{mL}$ ratio was based on these published observations - a Feridex concentration lower than the reported toxic concentration for cord MSC and a protamine concentration between 3 and $9 \mu \mathrm{g} / \mathrm{mL}$ to test the safety and the efficacy of MSC labeling.

Various concentrations of PLL have been used with $25 \mu \mathrm{g} / \mathrm{mL}$ of Feridex, e.g., $375 \mathrm{ng} / \mathrm{mL}$ [44] $750 \mathrm{ng} / \mathrm{mL}$ $[30,45]$ and $1500 \mathrm{ng} / \mathrm{mL}$ [46]. Since some authors have shown that the FePLL complexes can form toxic aggregates which are not incorporated by the cells [39], we chose a low, but efficient, concentration of PLL.

The MSCs were efficiently labeled with ferumoxide when combined with either facilitating agent, independent of whether the exposure time was short ( $4 \mathrm{hrs}$ ) or long-term $(24 \mathrm{hrs})$. These data corroborate a recent study that showed that the amount of intracellular SPIONs in cells exposed to FeProt for 4, 24 and 48 hours did not change whereas different concentrations of FeProt interfered with the amount of intracellular SPIONs [32]. However, when MSCs were incubated with ferumoxide in the absence of a facilitator the labeling of cells was negligible. Under these conditions incorporation was time dependent since after 24 hrs more Feridex incorporation occurred in the absence of facilitation than after 4 hrs of exposure.

In proliferation assays, we demonstrated that $4 \mathrm{hrs}$ of incubation with FePLL did not alter MSC proliferative capacity. However, after $24 \mathrm{hrs}$ of incubation with FePLL, we observed a reduction in proliferation rate that was not observed when MSCs were incubated with FeProt for either 4 or $24 \mathrm{hrs}$. The proliferation rate decrease observed in the FePLL 24 h group is dependent on the formation of FePLL complexes since incubation of the cells with PLL or Feridex alone did not affect proliferation rate. According to Kostura et. al. [39] the incorporation of FePLL complexes by MSCs affects their differentiation into chondrocytes. Incubation of PLL with Feridex can generate large FePLL complexes which can not be incorporated into endosomes and remain adhered to the cell membrane [31,40]. Recently it was demonstrated that labeling of MSCs with ferucarbotran, without an incorporation facilitator agent, inhibits chondrongenesis in a dose-dependent way. The authors suggest that surface binding of ferucarbotran SPIONs could inhibit surface-linked cell-cell interactions. This does not appear to happen when the MSCs are exposed to ferucarbotran associated with protamine because the compound can facilitate transport of the SPIONs into the intracellular compartment [47]. Our results show that the protocol using FeProt is superior to that using FePLL due to the toxicity observed when MSCs were cultivated with FePLL for 24 hrs.

It was suggested that relatively high concentrations of protamine (e.g., 5-6 $\mu \mathrm{g} / \mathrm{mL}$ ) form large extracellular complexes that are not incorporated by the cells but remain permanently attached to the cell membrane. Recently, some authors described an optimized protocol for cell labeling using lower concentrations of protamine and higher concentrations of Feridex than used in their previous studies. Formation of extracellular aggregates was not observed using this new protocol [32]. However, using the new optimized protocol, the authors did not test whether higher concentrations of protamine could induce the formation of extracellular complexes. In our study we propose an optimized protocol using a low concentration of Feridex and a higher concentration of protamine $(25: 5 \mu \mathrm{g} / \mathrm{mL}$ Fe:Prot). Using our protocol, extracellular aggregates attached to the MSC membrane were not observed by electron microscopy (unpublished 

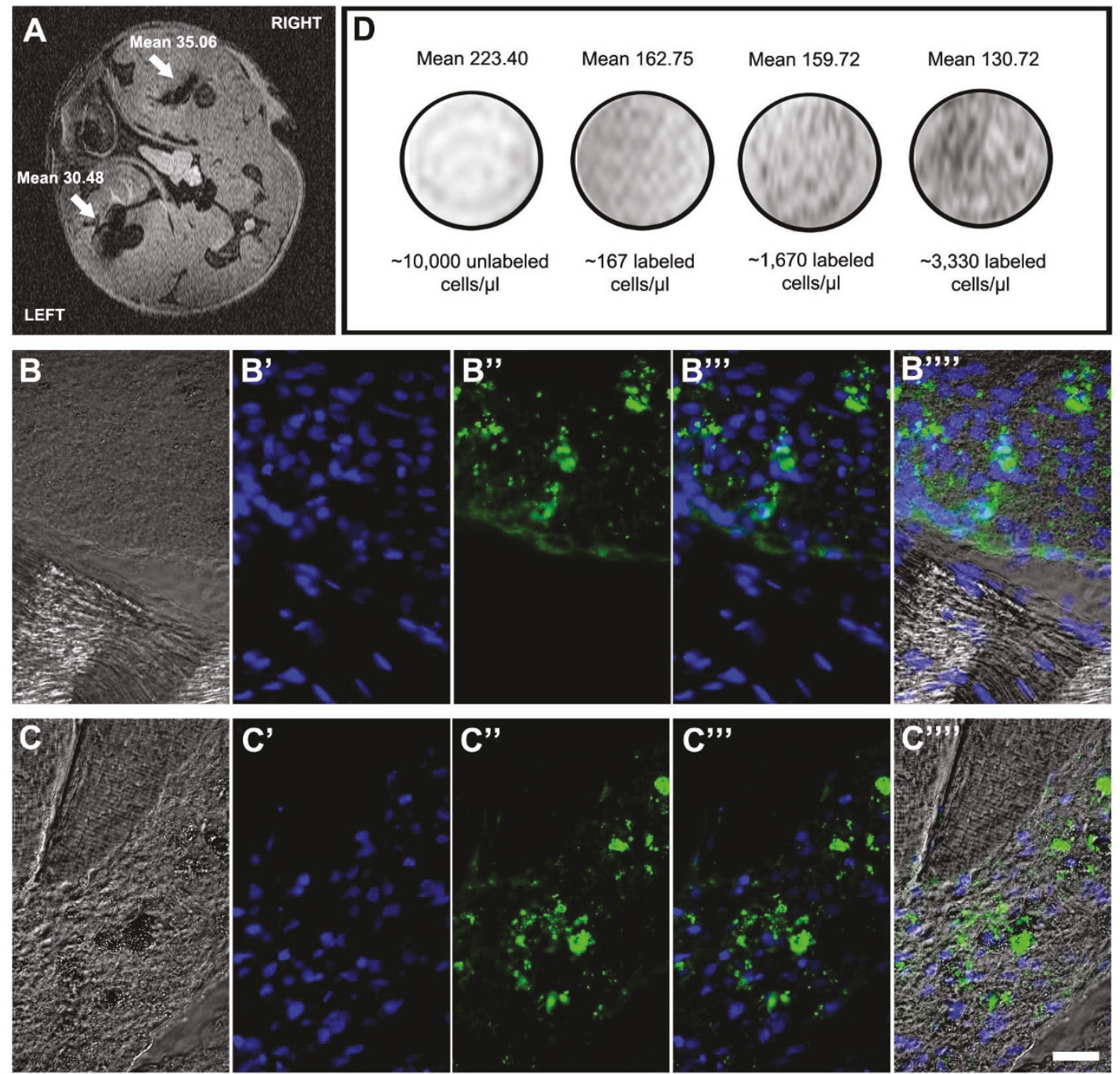

Figure 6 Detection of Feridex-labeled MSCs by in vivo and in vitro MRI. (A-C $\mathbf{C}^{\prime \prime \prime}$ ) Cells labeled with FeProt complexes for 4 or 24 hrs and injected in right or left leg muscles, respectively, were detected by in vivo MRI and by dextran immunofluorescence (A) Representative image of in vivo MRI (transverse plane) showing hypointense (black) spots corresponding to Feridex-labeled cells injected in the leg muscles (white arrows). (B-B'") Dextran immunocytochemistry confirming the presence of Feridex-labeled cells in the right leg muscle. (B) Phase contrast

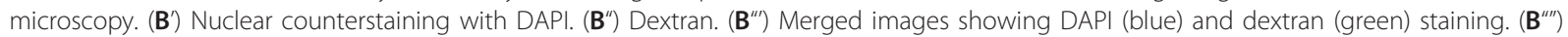
Merge of images with phase contrast. (C-C $\left.\mathbf{C}^{\prime \prime \prime}\right)$ Dextran immunohistochemistry confirming the presence of Feridex-labeled cells in the left leg

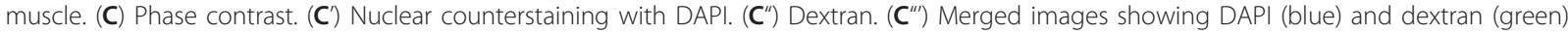

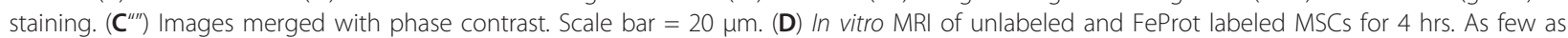
160 cells/ $\mu$ l could be detected by MRI. The "Mean" values are the mean intensities of the gray values in the range of 0-255.

data in collaboration with members of our laboratory, Louise Moraes and Wagner Monteiro Cintra).

Since protamine is clinically approved and does not alter proliferation rate, we performed a more extensive investigation evaluating FeProt complexes as candidates to label MSCs. We chose the protocol using a shortterm ( $4 \mathrm{hrs}$ ) exposure to FeProt because this is more suitable for clinical use. When we monitored the cells, injected in the mouse leg muscles, by in vivo MRI, there were no apparent differences in the hypointense dark spots resulting from the MSCs incubated for short or long time periods with FeProt. Moreover, we could detect even a small number of the $4 \mathrm{hr}$ FeProt labeled cells in the in vitro assays.

Other incorporation facilitators, besides protamine and PLL, have been used for cell labeling, such as FuGENE [13], Superfect and Lipofectamine [25] and some authors have not used any incorporation facilitator for cell labeling $[48,49]$. The primary advantage of the incubation labeling method is its simplicity. The primary 
disadvantage is the prolonged incubation time required [50]. Thus other approaches to induce labeling of freshly isolated cells such as magnetoelectroporation [51,52] and magnetosonoporation [53] appear to be better when the culture system must be avoided. Both techniques induce reversible eletromechanical permeability changes in the cell membranes, thereby facilitating the diffusion of MRI contrast agents.

Most authors have analyzed the effect of SPIONs on cell proliferation and viability by MTT (3-[4,5dimethylthia-zol-2-yl]-2,5-diphenyl tetrazolinum bromide) assays $[30,31,49]$. However, it has been shown that the MTT test is unsuitable for measuring either cell growth or proliferation [54-56]. In the present study, we analyzed MSC proliferation based on detection of the Ki67 protein and viability by live/dead assays for up to 7 days after initial exposure to SPIONs. We did not observe alterations in MSC proliferation rate at 3 or 7 days after the initial $4 \mathrm{hr}$ exposure to FeProt when compared with the respective controls. In addition, we analyzed the viability of MSCs after exposure to FeProt complexes. The viability was maintained after 4 or $24 \mathrm{hrs}$ of incubation and at 3 or 7 days after initial $4 \mathrm{hr}$ incubation with FeProt. Our results demonstrate that the number of cells labeled with Feridex is maintained after 7 days. However, after 21 days the number of labeled cells decreased by more than $65 \%$, mainly due to cellular proliferation because when we cultured the labeled MSCs at confluence (FeProt 21d group) or pre-treated the cells with mitomycin C (FeProt MitC group), we observed only small decreases of $32.8 \%$ and $19.4 \%$ in the Feridexlabeled cell number, respectively. Moreover, even the small decreases observed in FeProt 21d and FeProt MitC groups were probably due to ongoing proliferation, since measurements of the group pre-treated with mitomycin $C$ showed a sustained proliferation rate of $6.9 \%$ (data not shown). We believe that it is very important that a significant fraction of the cells retain the label in order to accurately report the distribution of the MSC population.

Although labeling of exogenous cells has been extensively used for tracking cells after transplantation, it is important to emphasize that endogenous cell labeling is essential for understanding the alterations of migratory activities in normal and injured organs and for the development of new therapies. Micrometer-sized superparamagnetic iron oxide particles (MPIOs) have been widely used for endogenous tracking of neural stem/progenitor cell migration from subventricular zone (SVZ) but are not yet clinically approved. Efficient endogenous labeling can be achieved using a large amount of MPIOs without an incorporation facilitator [19-21,57]. However, quantitative analysis of bromodeoxyuridine revealed altered proliferation in the SVZ and neural progenitor cells after in situ injection of MPIOs. When a small number of MPIOs was associated with PLL, labeling was more successful, and the proliferation in the SVZ was only marginally affected [21]. In our work we have focused on labeling of exogenous cells, but the knowledge about safe and efficient labeling is expected to be applicable to endogenous labeling as well.

Besides ferumoxides, ferucarbotran and gadolinium have also been used as clinical contrast agents for MRI and to label and track transplanted cells. Ferucarbotran (Resovist, Bayer Schering Pharma AG, Berlin, Germany) is a SPION coated with carboxydextran while ferumoxide (Feridex) is coated with dextran. It was suggested that the additional carboxyl groups associated with ferucarbotran might lead to a higher affinity to the cell membrane so that cells could be labeled with it without need of an incorporation facilitator $[48,49]$. However, recent work showed that a higher percentage of labeled cells, a higher amount of intracellular iron and lower amount of extracellular iron aggregates were reached using FeProt complexes when compared to Resovist without incorporation facilitator [33]. Moreover, in a study on human MSC (hMSC), there was no difference in the total iron content (pg/cell) among cells incubated with Feridex or Resovist when both were added together with PLL; both Feridex and Resovist incorporation was superior to a third type of nanoparticle [monocrystalline iron oxide (MION), an ultrasmall superparamagnetic iron oxide] when added with PLL [58]. Cell viability and proliferation were not altered in any condition. However, the levels of Oct-4 mRNA increased in labeled hMSC at day 1 but not at day 7 and a subpopulation of hMSCs expressing CD45 was observed after 7 days of culture.

Gadolinium nanoparticles are also clinically approved as contrast agents. Although gadolinium-labeled stem cells have been reported to be efficiently tracked by MRI [18,59], a significant increase in reactive oxygen species was observed at all time points (from 2 to $24 \mathrm{hrs}$ ) after cell labeling and a significant decrease in the proliferation rate was observed after 24 hours [60]. In addition, gadolinium-labeling can affect proteoglycan synthesis, cell proliferation and apoptosis of chondrocytes in a dose-dependent manner [61]. For these reasons, ferumoxides appear currently to be the preferred material for cell labeling and tracking.

For clinical protocol approval, it is essential to maintain the differentiation capacity of MSCs after exposure to FeProt complexes. The 4 hr Feridex labeled cells were induced to differentiate into adipocytes, osteocytes or chondrocytes and we observed that the differentiation capacity was unaffected by FeProt incorporation.

\section{Conclusion}

In summary, in this study we demonstrate that FePLL complexes affect cell proliferation after $24 \mathrm{hr}$ exposure. 
However, the protocol using FeProt complexes does not affect the proliferative capacity and cellular viability for up to 7 days after incorporation. In addition, the differentiation potential of labeled MSCs is not affected. Furthermore, the protocol using FeProt complexes can be applied to patients, since both ferumoxides and protamine are approved for human use and our results show that this protocol is efficient to track cells by MRI.

\section{Acknowledgements and Funding}

This work was supported by grants from the Conselho Nacional de Desenvolvimento Científico e Tecnológico (CNPq), Coordenação de Aperfeiçoamento de Pessoal de Nível Superior (CAPES), Fundação Carlos Chagas Filho de Amparo à Pesquisa do Estado do Rio de Janeiro (FAPERJ), Instituto Nacional de Ciência e Tecnologia de Biologia Estrutural e Bioimagem (INBEB) and National Institutes of Health: Fogarty training grant (D43-TW007129) and RO1 (HL73732).

\section{Author details \\ ${ }^{1}$ Instituto de Biofísica Carlos Chagas Filho, Universidade Federal do Rio de Janeiro, Rio de Janeiro, Brazil. ${ }^{2}$ Dept. of Neuroscience, Albert Einstein College of Medicine, Bronx, NY, USA. ${ }^{3}$ Dept. of Physiology and Biophysics, Albert Einstein College of Medicine, Bronx, NY, USA. ${ }^{4}$ Hospital Universitário Clementino Fraga Filho, Universidade Federal do Rio de Janeiro, Rio de Janeiro, Brazil.}

\section{Authors' contributions}

$\mathrm{J}$ conceived of the study, participated in the design, collection and assembly of data, performed the statistical analysis, interpretation and drafted the manuscript. ALMT, HMPN and JAP assisted with collection and assembly of data and performed the statistical analysis. LAJ collected data and helped draft the manuscript. ELG conceived of the study, participated in its design and coordinated its execution. DCS, ACCC and RMO conceived of the study, participated in its design and coordination and drafted the manuscript. All authors read and approved the final manuscript.

\section{Competing interests}

The authors declare that they have no competing interests.

Received: 11 October 2010 Accepted: 9 February 2011

Published: 9 February 2011

\section{References}

1. Orlic D, Kajstura J, Chimenti S, Limana F, Jakoniuk I, Quaini F, NadalGinard B, Bodine DM, Leri A, Anversa P: Mobilized bone marrow cells repair the infarcted heart, improving function and survival. Proc Natl Acad Sci USA 2001, 98:10344-10349.

2. Wu J, Sun Z, Sun HS, Weisel RD, Keating A, Li ZH, Feng ZP, Li RK: Intravenously administered bone marrow cells migrate to damaged brain tissue and improve neural function in ischemic rats. Cell Transplant 2008, 16:993-1005.

3. Pittenger MF, Mackay AM, Beck SC, Jaiswal RK, Douglas R, Mosca JD, Moorman MA, Simonetti DW, Craig S, Marshak DR: Multilineage potential of adult human mesenchymal stem cells. Science 1999, 284:143-147.

4. Toma C, Pittenger MF, Cahill KS, Byrne BJ, Kessler PD: Human mesenchymal stem cells differentiate to a cardiomyocyte phenotype in the adult murine heart. Circulation 2002, 105:93-98.

5. Barry FP, Murphy JM: Mesenchymal stem cells: clinical applications and biological characterization. Int J Biochem Cell Biol 2004, 36:568-584.

6. Di Nicola M, Carlo-Stella C, Magni M, Milanesi M, Longoni PD, Matteucci P, Grisanti S, Gianni AM: Human bone marrow stromal cells suppress T-lymphocyte proliferation induced by cellular or nonspecific mitogenic stimuli. Blood 2002, 99:3838-3843.

7. Krampera M, Glennie S, Dyson J, Scott D, Laylor R, Simpson E, Dazzi F: Bone marrow mesenchymal stem cells inhibit the response of naive and memory antigen-specific T cells to their cognate peptide. Blood 2003, 101:3722-3729.
8. Meisel R, Zibert A, Laryea M, Gobel U, Daubener W, Dilloo D: Human bone marrow stromal cells inhibit allogeneic T-cell responses by indoleamine 2,3-dioxygenase-mediated tryptophan degradation. Blood 2004, 103:4619-4621

9. Zhang W, Ge W, Li C, You S, Liao L, Han Q, Deng W, Zhao RC: Effects of mesenchymal stem cells on differentiation, maturation, and function of human monocyte-derived dendritic cells. Stem Cells Dev 2004 13:263-271.

10. Sotiropoulou PA, Perez SA, Salagianni M, Baxevanis CN, Papamichail M: Characterization of the optimal culture conditions for clinical scale production of human mesenchymal stem cells. Stem Cells 2006, 24:462-471

11. Guzman R, Uchida N, Bliss TM, He D, Christopherson KK, Stellwagen D, Capela A, Greve J, Malenka RC, Moseley ME, et al: Long-term monitoring of transplanted human neural stem cells in developmental and pathological contexts with MRI. Proc Natl Acad Sci USA 2007, 104:10211-10216.

12. Sykova E, Jendelova P: Migration, fate and in vivo imaging of adult stem cells in the CNS. Cell Death Differ 2007, 14:1336-1342.

13. Hoehn M, Kustermann E, Blunk J, Wiedermann D, Trapp T, Wecker S, Focking M, Arnold H, Hescheler J, Fleischmann BK, et al: Monitoring of implanted stem cell migration in vivo: a highly resolved in vivo magnetic resonance imaging investigation of experimental stroke in rat. Proc Natl Acad Sci USA 2002, 99:16267-16272.

14. Dodd SJ, Williams M, Suhan JP, Williams DS, Koretsky AP, Ho C: Detection of single mammalian cells by high-resolution magnetic resonance imaging. Biophys J 1999, 76:103-109.

15. Jendelova P, Herynek V, Urdzikova L, Glogarova K, Kroupova J, Andersson B, Bryja V, Burian M, Hajek M, Sykova E: Magnetic resonance tracking of transplanted bone marrow and embryonic stem cells labeled by iron oxide nanoparticles in rat brain and spinal cord. J Neurosci Res 2004, 76:232-243.

16. Shapiro EM, Skrtic S, Sharer K, Hill JM, Dunbar CE, Koretsky AP: MRI detection of single particles for cellular imaging. Proc Natl Acad Sci USA 2004, 101:10901-10906.

17. Farrell E, Wielopolski $P$, Pavliasevic $P$, van Tiel $S$, Jahr $H$, Verhaar J, Weinans H, Krestin G, O'Brien FJ, van Osch G, Bernsen M: Effects of iron oxide incorporation for long term cell tracking on MSC differentiation in vitro and in vivo. Biochem Biophys Res Commun 2008, 369:1076-1081.

18. Modo M, Cash D, Mellodew K, Williams SC, Fraser SE, Meade TJ, Price J, Hodges H: Tracking transplanted stem cell migration using bifunctional, contrast agent-enhanced, magnetic resonance imaging. Neuroimage 2002, 17:803-811.

19. Yang J, Liu J, Niu G, Chan KC, Wang R, Liu Y, Wu EX: In vivo MRI of endogenous stem/progenitor cell migration from subventricular zone in normal and injured developing brains. Neuroimage 2009, 48:319-328.

20. Shapiro EM, Gonzalez-Perez O, Manuel Garcia-Verdugo J, Alvarez-Buylla A, Koretsky AP: Magnetic resonance imaging of the migration of neuronal precursors generated in the adult rodent brain. Neuroimage 2006, 32:1150-1157.

21. Vreys R, Vande Velde G, Krylychkina O, Vellema M, Verhoye M, Timmermans JP, Baekelandt V, Van der Linden A: MRI visualization of endogenous neural progenitor cell migration along the RMS in the adult mouse brain: validation of various MPIO labeling strategies. Neuroimage 2010, 49:2094-2103.

22. Lewin M, Carlesso N, Tung CH, Tang XW, Cory D, Scadden DT, Weissleder R: Tat peptide-derivatized magnetic nanoparticles allow in vivo tracking and recovery of progenitor cells. Nat Biotechnol 2000, 18:410-414.

23. Dodd CH, Hsu HC, Chu WJ, Yang P, Zhang HG, Mountz JD Jr, Zinn K, Forder J, Josephson L, Weissleder R, et al: Normal T-cell response and in vivo magnetic resonance imaging of T cells loaded with HIV transactivator-peptide-derived superparamagnetic nanoparticles. J Immunol Methods 2001, 256:89-105.

24. Ahrens ET, Feili-Hariri M, Xu H, Genove G, Morel PA: Receptor-mediated endocytosis of iron-oxide particles provides efficient labeling of dendritic cells for in vivo MR imaging. Magn Reson Med 2003, 49:1006-1013.

25. Frank JA, Miller BR, Arbab AS, Zywicke HA, Jordan EK, Lewis BK, Bryant LH $\mathrm{Jr}$, Bulte JW: Clinically applicable labeling of mammalian and stem cells by combining superparamagnetic iron oxides and transfection agents. Radiology 2003, 228:480-487. 
26. Ferrucci JT, Stark DD: Iron oxide-enhanced MR imaging of the liver and spleen: review of the first 5 years. AJR Am J Roentgenol 1990, 155:943-950.

27. Weissleder R, Stark DD, Engelstad BL, Bacon BR, Compton CC, White DL, Jacobs P, Lewis J: Superparamagnetic iron oxide: pharmacokinetics and toxicity. AJR Am J Roentgenol 1989, 152:167-173.

28. Molday RS, MacKenzie D: Immunospecific ferromagnetic iron-dextran reagents for the labeling and magnetic separation of cells. J Immunol Methods 1982, 52:353-367.

29. Babic M, Horak D, Trchova M, Jendelova P, Glogarova K, Lesny P, Herynek V, Hajek M, Sykova E: Poly(L-lysine)-modified iron oxide nanoparticles for stem cell labeling. Bioconjug Chem 2008, 19:740-750

30. Arbab AS, Bashaw LA, Miller BR, Jordan EK, Bulte JW, Frank JA: Intracytoplasmic tagging of cells with ferumoxides and transfection agent for cellular magnetic resonance imaging after cell transplantation: methods and techniques. Transplantation 2003, 76:1123-1130.

31. Arbab AS, Yocum GT, Kalish H, Jordan EK, Anderson SA, Khakoo AY, Read EJ, Frank JA: Efficient magnetic cell labeling with protamine sulfate complexed to ferumoxides for cellular MRI. Blood 2004, 104:1217-1223.

32. Janic B, Rad AM, Jordan EK, Iskander AS, Ali MM, Varma NR, Frank JA, Arbab AS: Optimization and validation of FePro cell labeling method. Plos One 2009, 4:e5873.

33. van Buul GM, Farrell E, Kops N, van Tiel ST, Bos PK, Weinans H, Krestin GP, van Osch GJ, Bernsen MR: Ferumoxides-protamine sulfate is more effective than ferucarbotran for cell labeling: implications for clinically applicable cell tracking using MRI. Contrast Media Mol Imaging 2009, 4:230-236

34. Reynolds F, Weissleder R, Josephson L: Protamine as an efficient membrane-translocating peptide. Bioconjug Chem 2005, 16:1240-1245.

35. Bull BS, Huse WM, Brauer FS, Korpman RA: Heparin therapy during extracorporeal circulation. II. The use of a dose-response curve to individualize heparin and protamine dosage. J Thorac Cardiovasc Surg 1975, 69:685-689.

36. Gervin AS: Complications of heparin therapy. Surg Gynecol Obstet 1975 140:789-796.

37. Sorgi FL, Bhattacharya S, Huang L: Protamine sulfate enhances lipidmediated gene transfer. Gene Ther 1997, 4:961-968.

38. Reddy AM, Kwak BK, Shim HJ, Ahn C, Cho SH, Kim BJ, Jeong SY, Hwang SJ, Yuk SH: Functional characterization of mesenchymal stem cells labeled with a novel PVP-coated superparamagnetic iron oxide. Contrast Media Mol Imaging 2009, 4:118-126.

39. Kostura L, Kraitchman DL, Mackay AM, Pittenger MF, Bulte JW: Feridex labeling of mesenchymal stem cells inhibits chondrogenesis but not adipogenesis or osteogenesis. NMR Biomed 2004, 17:513-517.

40. Arbab AS, Yocum GT, Rad AM, Khakoo AY, Fellowes V, Read EJ, Frank JA: Labeling of cells with ferumoxides-protamine sulfate complexes does not inhibit function or differentiation capacity of hematopoietic or mesenchymal stem cells. NMR Biomed 2005, 18:553-559.

41. Bourrinet $P$, Bengele $H H$, Bonnemain B, Dencausse A, Idee JM, Jacobs PM, Lewis JM: Preclinical safety and pharmacokinetic profile of ferumoxtran10 , an ultrasmall superparamagnetic iron oxide magnetic resonance contrast agent. Invest Radiol 2006, 41:313-324.

42. Walczak P, Zhang J, Gilad AA, Kedziorek DA, Ruiz-Cabello J, Young RG, Pittenger MF, van Zijl PC, Huang J, Bulte JW: Dual-modality monitoring of targeted intraarterial delivery of mesenchymal stem cells after transient ischemia. Stroke 2008, 39:1569-1574.

43. Hu SL, Zhang JQ, Hu X, Hu R, Luo HS, Li F, Xia YZ, Li JT, Lin JK, Zhu G, Feng $H$ : In vitro labeling of human umbilical cord mesenchymal stem cells with superparamagnetic iron oxide nanoparticles. J Cell Biochem 2009, 108:529-535.

44. Walczak P, Kedziorek DA, Gilad AA, Barnett BP, Bulte JW: Applicability and limitations of MR tracking of neural stem cells with asymmetric cell division and rapid turnover: the case of the shiverer dysmyelinated mouse brain. Magn Reson Med 2007, 58:261-269.

45. Yocum GT, Wilson LB, Ashari P, Jordan EK, Frank JA, Arbab AS: Effect of human stem cells labeled with ferumoxides-poly-L-lysine on hematologic and biochemical measurements in rats. Radiology 2005, 235:547-552.

46. Ramaswamy S, Greco JB, Uluer MC, Zhang Z, Fishbein KW, Spencer RG: Magnetic resonance imaging of chondrocytes labeled with superparamagnetic iron oxide nanoparticles in tissue-engineered cartilage. Tissue Eng Part A 2009, 15:3899-3910.
47. Henning TD, Sutton EJ, Kim A, Golovko D, Horvai A, Ackerman L, Sennino B, McDonald D, Lotz J, Daldrup-Link HE: The influence of ferucarbotran on the chondrogenesis of human mesenchymal stem cells. Contrast Media Mol Imaging 2009, 4:165-173.

48. Mailander V, Lorenz MR, Holzapfel V, Musyanovych A, Fuchs K, Wiesneth M, Walther P, Landfester K, Schrezenmeier H: Carboxylated superparamagnetic iron oxide particles label cells intracellularly without transfection agents. Mol Imaging Biol 2008, 10:138-146.

49. Hsiao JK, Tai MF, Chu HH, Chen ST, Li H, Lai DM, Hsieh ST, Wang JL, Liu HM: Magnetic nanoparticle labeling of mesenchymal stem cells without transfection agent: cellular behavior and capability of detection with clinical $1.5 \mathrm{~T}$ magnetic resonance at the single cell level. Magn Reson Med 2007, 58:717-724.

50. Qiu B, Yang X: Molecular MRI of hematopoietic stem-progenitor cells: in vivo monitoring of gene therapy and atherosclerosis. Nat Clin Pract Cardiovasc Med 2008, 5:396-404.

51. Walczak P, Kedziorek DA, Gilad AA, Lin S, Bulte JW: Instant MR labeling of stem cells using magnetoelectroporation. Magn Reson Med 2005, 54:769-774.

52. Tai JH, Foster P, Rosales A, Feng B, Hasilo C, Martinez $V$, Ramadan S, Snir J, Melling CW, Dhanvantari $S$, et al: Imaging islets labeled with magnetic nanoparticles at 1.5 Tesla. Diabetes 2006, 55:2931-2938.

53. Qiu B, Xie D, Walczak P, Li X, Ruiz-Cabello J, Minoshima S, Bulte JW, Yang X: Magnetosonoporation: instant magnetic labeling of stem cells. Magn Reson Med 2010, 63:1437-1441.

54. Klein CL, Wagner M, Kirkpatrick CJ, Van Kooten TG: A new quantitative test method for cell proliferation based on detection of the Ki-67 protein J Mater Sci Mater Med 2000, 11:125-132.

55. Wang P, Henning SM, Heber D: Limitations of MTT and MTS-based assays for measurement of antiproliferative activity of green tea polyphenols. PLoS One 2010, 5:e10202.

56. Liu Y, Peterson DA, Kimura H, Schubert D: Mechanism of cellular 3-(4,5dimethylthiazol-2-yl)-2,5-diphenyltetrazolium bromide (MTT) reduction. J Neurochem 1997, 69:581-593.

57. Nieman BJ, Shyu JY, Rodriguez JJ, Garcia AD, Joyner AL, Turnbull DH: In vivo $\mathrm{MRI}$ of neural cell migration dynamics in the mouse brain. Neuroimage 2010, 50:456-464

58. Kim HS, Oh SY, Joo HJ, Son KR, Song IC, Moon WK: The effects of clinically used MRI contrast agents on the biological properties of human mesenchymal stem cells. NMR Biomed 2010, 23:514-522.

59. Modo M, Mellodew K, Cash D, Fraser SE, Meade TJ, Price J, Williams SC: Mapping transplanted stem cell migration after a stroke: a serial, in vivo magnetic resonance imaging study. Neuroimage 2004, 21:311-317.

60. Brekke C, Morgan SC, Lowe AS, Meade TJ, Price J, Williams SC, Modo M: The in vitro effects of a bimodal contrast agent on cellular functions and relaxometry. NMR Biomed 2007, 20:77-89.

61. Greisberg JK, Wolf JM, Wyman J, Zou L, Terek RM: Gadolinium inhibits thymidine incorporation and induces apoptosis in chondrocytes. J Orthop Res 2001, 19:797-801.

doi:10.1186/1477-3155-9-4

Cite this article as: Jasmin et al:: Optimized labeling of bone marrow mesenchymal cells with superparamagnetic iron oxide nanoparticles and in vivo visualization by magnetic resonance imaging. Journal of Nanobiotechnology 2011 9:4.

\section{Submit your next manuscript to BioMed Central and take full advantage of:}

- Convenient online submission

- Thorough peer review

- No space constraints or color figure charges

- Immediate publication on acceptance

- Inclusion in PubMed, CAS, Scopus and Google Scholar

- Research which is freely available for redistribution 